\title{
ANALISIS KINERJA PEGAWAI PADA BADAN PENGELOLAAN KEUANGAN DAN ASET DAERAH KABUPATEN LAMPUNG UTARA
}

\author{
Andy Fitriyadi Dharmat Tilaar \\ Program Studi Manajemen Sekolah Tinggi Ilmu Ekonomi Gentiaras Lampung \\ Email: Ms006zeta2001@yahoo.com
}

\begin{abstract}
Imiah Studies in Dinas Sosial, Tenaga Kerja dan Transmigrasi Kabupaten Lampung Tengah in 2015 to uncover performance issues. It is attracting writers to research and study further by testing and analyzing the extent to which "The Influence of Leadership Styles and Motivation Work To Performance Employees Dinas Sosial, Tenaga Kerja dan Transmigrasi Kabupaten Lampung Tengah ". The hypothesis is: Suspected leadership style and work motivation affect the performance of Social Service Employees Manpower and Dinas Sosial, Tenaga Kerja dan Transmigrasi Kabupaten Lampung Tengah. This research was conducted using survey method. The entire population is in the Employee Dinas Sosial, Tenaga Kerja dan Transmigrasi Kabupaten Lampung Tengah regency as many as 55 people, in which samples were taken using saturated sample. The reliability of the instrument is calculated by the formula product moment correlation, while the reliability of the instrument is calculated by the formula Alpha crobach.

Results of research leadership style and work motivation affect the performance of Dinas Sosial, Tenaga Kerja dan Transmigrasi Kabupaten Lampung Tengah with a coefficient of determination of 43.3\% (percent) of the variation of the effect of changes in leadership style and work motivation may explain Employee Performance and Dinas Sosial, Tenaga Kerja dan Transmigrasi Kabupaten Lampung Tengah. Whereas $56.7 \%$ (percent) the rest is the influence of variables or other factors outside the model.
\end{abstract}

Keywords: Leadership Style, Work Motivation, Employee Performance

\section{PENDAHULUAN}

\subsection{Latar Belakang}

Berdasarkan Undang-Undang Nomor 25 Tahun 2004 tentang Sistem Perencanaan Pembangunan Nasional, menyatakan bahwa Sistem Perencanaan Pembangunan Nasional, adalah satu kesatuan tata cara perencanaan pembangunan, untuk menghasilkan rencanarencana pembangunan dalam jangka panjang (dua puluh tahunan), jangka menengah (lima tahunan), dan jangka pendek (satu tahunan), yang dilaksanakan oleh unsur penyelenggara negara dan masyarakat di tingkat Pusat dan Daerah.

Mekanisme

perencanaan

pembangunan terdiri dari empat tahapan yakni: (1) penyusunan rencana; (2) penetapan rencana; (3) pengendalian pelaksanaan rencana; dan (4) evaluasi pelaksanaan rencana. Keempat tahapan tersebut diselenggarakan secara kontinu serta berkelanjutan, sehingga secara keseluruhan membentuk satu siklus perencanaan yang utuh dan bulat.

Produk dari Perencanaan

Pembangunan Daerah tersebut diantaranya terdiri dari: a. rencana pembangunan jangka panjang daerah; b. rencana pembangunan jangka menengah daerah; dan c. rencana pembangunan jangka pendek ( tahunan ). Sedangkan Rencana Strategis Satuan Kerja Perangkat Daerah (Renstra-SKPD), Badan Pengelolaan Keuangan dan Aset Kabupaten Lampung Utara, adalah dokumen perencanaan Satuan Kerja Perangkat Daerah Kabupaten Lampung Utara, untuk periode 5 (lima) tahun, yang merupakan dokumen perencanaan teknis operasional. Dengan substansi terdiri dari visi, misi, tujuan strategi, kebijakan, program dan kegiatan pembangunan, yang diselaraskan 
dengan tugas pokok dan fungsi, Badan Pengelolaan Keuangan dan Aset Kabupaten Lampung Utara, serta merupakan penjabaran dari Rencana Pembangunan Jangka Menengah Daerah (RPJMD) Kabupaten Lampung Utara, untuk jangka waktu lima tahunan, yang penyusunannya mengacu kepada sejumlah dokumen perencanaan yang terkait, seperti RTRW, Renstra Kementerian PPN/Bappenas, Renstra Bappeda Provinsi Lampung, dan sejumlah dokumen perencanaan terkait lainnya.

Dalam rangka mengejawantahkan Peraturan Daerah Kabupaten Lampung Utara Nomor 01 Tahun 2015 tentang Rencana Pembangunan Jangka Menengah Daerah Kabupaten Lampung Utara Tahun 2014-2019, serta sebagai bentuk pelaksanaan Peraturan Menteri Dalam Negeri Nomor 54 Tahun 2010, tentang Pelaksanaan Peraturan Pemerintah Nomor 8 Tahun 2008 tentang Tahapan, Tata
Cara Penyusunan, Pengendalian dan Evaluasi Pelaksanaan Rencana Pembangunan Daerah, yang mengamanatkan setiap Satuan Kerja Perangkat Daerah ( SKPD ), harus memiliki Rencana Strategis Satuan Kerja Perangkat Daerah ( RENSTRA - SKPD ), sebagai penjabaran lebih rinci dari Rencana Pembangunan Jangka Menengah Daerah (RPJMD), termasuk dalam hal ini Badan Pengelolaan Keuangan dan Aset Kabupaten Lampung Utara. Maka dilakukanlah perumusan Rencana Strategis Satuan Kerja Perangkat Daerah ( RENSTRA - SKPD ) Tahun 2014 - 2019, Sebagai dokumen perencanaan pembangunan 5 ( lima ) tahunan, Badan Pengelolaan Keuangan dan Aset Kabupaten Lampung Utara. Kemudian berikut di jelaskan fluktasi penyelesaian kegiatan pekerjaan pada Badan Pengelolaan Keuangan dan Aset Kabupaten Lampung Utara selama 8 bulan terakhir.

Tabel 1.

Presensi dan Prestasi Pegawai Badan Pengelolaan Keuangan dan Aset Kabupaten Lampung Utara

\begin{tabular}{ccccc}
\hline & & Fluktasi & \multicolumn{2}{c}{ Pekerjaan } \\
\hline Bulan & Tahun & Presentase Kehadiran & Selesai & Tidak Selesai \\
\hline Mei & 2015 & $85 \%$ & $80 \%$ & $20 \%$ \\
\hline Juni & 2015 & $90 \%$ & $80 \%$ & $20 \%$ \\
\hline Juli & 2015 & $95 \%$ & $70 \%$ & $30 \%$ \\
\hline Agustus & 2015 & $80 \%$ & $80 \%$ & $20 \%$ \\
\hline September & 2015 & $95 \%$ & $70 \%$ & $30 \%$ \\
\hline Oktober & 2015 & $80 \%$ & $70 \%$ & $30 \%$ \\
\hline November & 2015 & $75 \%$ & $80 \%$ & $20 \%$
\end{tabular}

Sumber : Badan Pengelolaan Keuangan dan Aset Kabupaten Lampung Utara 2015

Berdasarkan data tersebut terlihat adanya fluktuasi hasil kerja yang terjadi pada Badan Pengelolaan Keuangan dan Aset Kabupaten Lampung Utara akibat kepuasan kerja guna memaksimalkan hasil kerja yang akan terjadi pada Badan Pengelolaan Keuangan dan Aset Kabupaten Lampung Utara dan merupakan cita - cita Badan Pengelolaan Keuangan dan Aset Kabupaten Lampung Utara dalam memproduktifkan pegawainya.
Kemudian beberapa fakta selanjutnya adalah faktor pimpinan yang diduga ikut mempengaruhi kinerja pegawai Badan Pengelolaan Keuangan dan Aset Kabupaten Lampung Utara, yang terjadi dan untuk itu berikut ditampilkan pendapat pegawai tentang pimpinan yang ada pada Badan Pengelolaan Keuangan dan Aset Kabupaten Lampung Utara dalam grafik sebagai berikut: 
Gambar 1

Pendapat Pegawai pada Pimpinan Dinas Badan Pengelolaan Keuangan dan Aset Kabupaten Lampung Utara

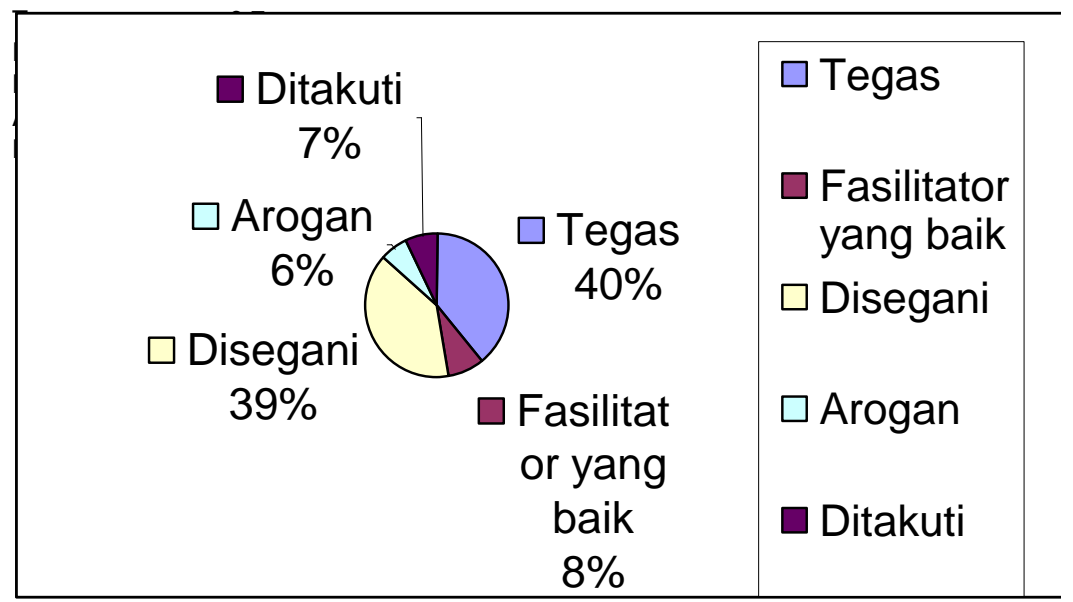

Sumber : Badan Pengelolaan Keuangan dan Aset Kabupaten Lampung Utara 2019

Berdasarkan gambar tersebut berbagai pendapat tentang pimpinan terjadi pada Badan Pengelolaan Keuangan dan Aset Kabupaten Lampung Utara hal ini memberikan ketertarikan peneliti dalam melakukan pengkajian lebih lanjut tentang dampak gaya kepemimpinan yang paling ideal yang akan dilakukan pada Badan Pengelolaan Keuangan dan Aset Kabupaten Lampung Utara agar dapat mengoptimalkan kinerja pegawai.

Selain faktor gaya kepemimpinan faktor lain yang diduga peneliti ikut berperan dalam mempengaruhi kinerja pegawai Dinas Badan Pengelolaan Keuangan dan Aset Kabupaten Lampung Utara adalah motivasi dari sisi pegawai yang menjadi penting disebabkan adanya pemikiran bahwa dengan motivasi yang tinggi maka kinerja juga akan menjadi lebih baik, dan berikut ini dijelaskan dalam gambar pendapat pegawai Badan Pengelolaan Keuangan dan Aset Kabupaten Lampung Utara tentang pengetahuannya akan organisasi tersebut.

Gambar 2.

Pendapat Pegawai pada pekerjaan mereka di Badan Pengelolaan Keuangan dan Aset Kabupaten Lampung Utara

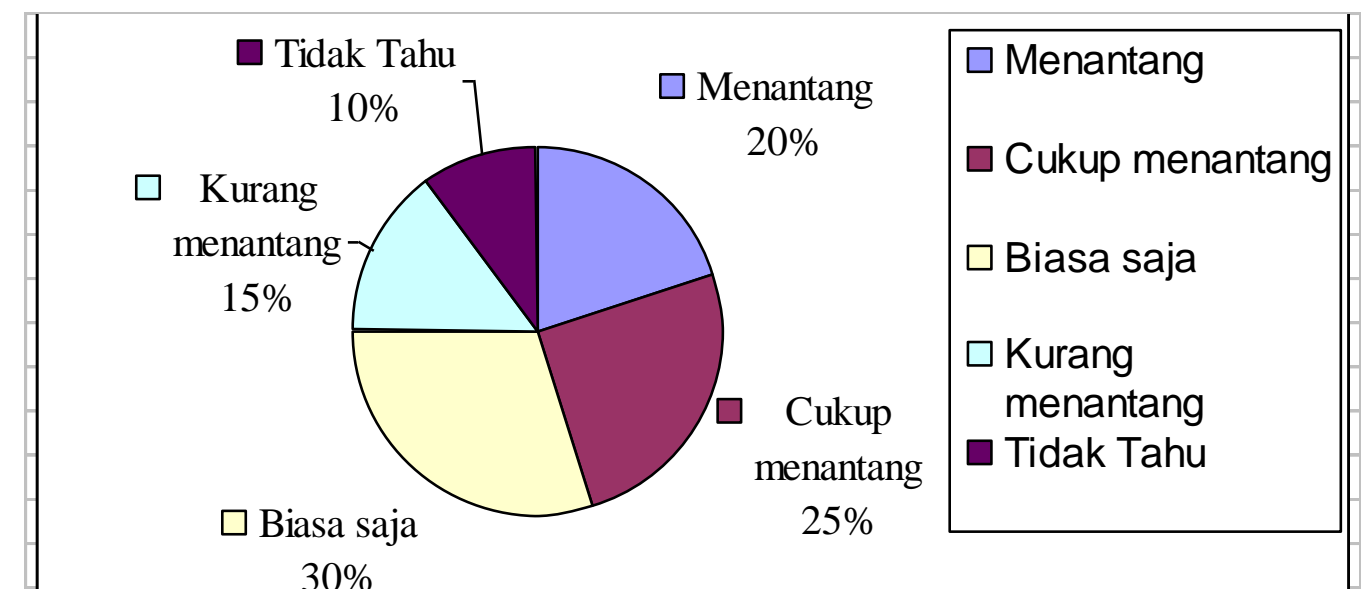

Sumber : Badan Pengelolaan Keuangan dan Aset Kabupaten Lampung Utara 2019 
Berdasarkan gambar tersebut diketahui masih adanya pegawai yang kurang mengetahui pekerjaannya, dan adanya dugaan memiliki semangat yang kurang pada pegawai yang menganggap pekerjaannya biasa saja dan kurang menantang hal ini memberikan juga ketertarikan peneliti untuk mengkaji lebih jauh tentang pengetahuan pegawai tersebut dalam motivasi kerjanya.

Berdasarkan hal - hal di atas tersebut, maka peneliti melakukan kajian ilmiah di Badan Pengelolaan Keuangan dan Aset Kabupaten Lampung Utara tahun 2019 untuk mengungkap masalah kinerja. Hal ini menarik minat penulis untuk meneliti dan mengkaji lebih lanjut dengan cara menguji dan menganalisis sejauh mana "Pengaruh Kepuasan Kerja dan Gaya Kepemimpinan Terhadap Kinerja Pegawai Badan Pengelolaan Keuangan dan Aset Kabupaten Lampung Utara". Fokus penelitian pada Kepuasan Kerja, Gaya Kepemimpinan, dan Kinerja Pegawai..

\subsection{Perumusan Masalah}

1. Apakah Kepuasan Kerja berpengaruh terhadap Kinerja Pegawai Dinas Badan Pengelolaan Keuangan dan Aset Kabupaten Lampung Utara?

2. Apakah Gaya Kepemimpinan berpengaruh terhadap Kinerja Pegawai Badan Pengelolaan Keuangan dan Aset Kabupaten Lampung Utara?

3. Apakah Kepuasan Kerja dan Gaya Kepemimpinan berpengaruh terhadap Kinerja Pegawai Dinas Sosial Badan Pengelolaan Keuangan dan Aset Kabupaten Lampung Utara?

\subsection{Tujuan Penelitian}

1. Untuk menjelaskan sejauhmana pengaruh Kepuasan Kerja terhadap Kinerja Pegawai Dinas Badan Pengelolaan Keuangan dan Aset Kabupaten Lampung Utara.

2. Untuk menjelaskan sejauhmana pengaruh Gaya Kepemimpinan terhadap Kinerja Pegawai Badan Pengelolaan Keuangan dan Aset Kabupaten Lampung Utara.

3. Untuk menjelaskan sejauhmana pengaruh Kepuasan Kerja dan Gaya Kepemimpinan terhadap Kinerja Pegawai Badan
Pengelolaan Keuangan dan Aset Kabupaten Lampung Utara.

\section{TINJAUAN PUSTAKA}

Konsep merupakan unsur dasar yang digunakan untuk membentuk teori. Aspekaspek teoritis yang akan dibahas diharapkan akan mendukung atau menjadi landasan dalam menelaah masalah penelitian yang telah dirumuskan, serta dapat memberikan dasar bagi peneliti dalam mengolah data, membahas hasil dan menarik kesimpulan penelitian.

\subsection{Kepuasan kerja}

Untuk mengetahui apakah individu merasa puas atau tidak puas dalam situasi tertentu, biasanya digunakan empat teori, yaitu teori pemenuhan (fulfill-ment theory ), teori imbalan (reward theory), teori kesenjangan (discrepancy theory), dan teori keadilan (equity theory). Luthans (2012) menguraikan penjelasan mengenai keempat teori sebagai berikut :

a. Teori Pemenuhan (fulfillment theory); Berdasarkan teori ini, kepuasan kerja kerja adalah fungsi dari kepuasan kerja terhadap terpenuhinya kebutuhan individu.

b. Teori Imbalan (Reward theory); Kemungkinan teori yang paling dapat digunakan untuk mengetahui kepuasan kerja kerja adalah teori imbalan, yang menjelaskan bahwa kepuasan kerja merupakan fungsi dari imbalan yang diterima oleh seseorang.

c. Teori Kesenjangan (Discrepancy theory) Kepuasan kerja dipengaruhi oleh harapanharapan dari karyawan. Teori discrepancy, menyatakan bahwa kepuasan kerja kerja merupakan hasil dari perbandingan antara apa yang diharapkan dan apa kenyataannya.

d. Teori Keadilan (Equity theory); Teori lain yang dapat digunakan untuk menentukan kepuasan kerja kerja dengan memfokuskan pada perbandingan relatif antara input dan hasil dari individu dengan input dan hasil dari individu lainnya adalah teori keadilan. Pada umumnya faktor-faktor yang mempengaruhi kepuasan kerja karyawan diklasifikasikan menjadi dua kelompok, 
yaitu yang bersumber dari dalam diri individu dan lingkungan (Nimran, 2004: 163). Bersumber dari dalam diri individu.

Faktor-faktor yang Bersumber dari dalam Diri Individu 1) Demografi (Demography); 2) Kecakapan (Ability); 3) Karakteristik Kepribadian (Personality). Faktorfaktor yang bersumber dari Lingkungan; 1) Job and job environment; 2) Organization environment; 3) Occupational Level (Tingkat pekerjaan).

Sedangkan yang menjadi dimensi kepuasan kerja menurut Smith, Kendall dalam Luthans (2012 : 144) yaitu :

1. The work it self; Menurut Luthans :the extent to which the job provides the individual with interest task, opportunities for learning, and chance to accept responsibility". Isi dari pekerjaan itu merupakan sumber utama bagi kepuasan kerja, dimana pemberian tugas-tugas menarik, kesempatan belajar, dan bertanggung jawab dapat membangkitkan motivasi sebagai umpan balik dari pekerjaan tersebut.

2. Pay; Selanjutnya Luthans memberikan definisi "the amount of financial renumeration that is received and the degree to which this is viewed as eqitable vis-à-vis others in the organization". Jumlah upah yang diterima dan tingkatannya yang terlihat sebagai penyesuaian, berbeda dengan yang lain dalam organisasi.

3. Promotion Opportunities; Dijelaskan oleh Luthans (2012 : 145) mengatakan : "the chances for advancement in the hierarchy", artinya bahwa dalam melaksanakan kebijakan pemberian kesempatan promosi kepada karyawan, maka pihak perusahaan harus memberikan kesempatan kepada karyawannya, agar karyawan mempunyai pegangan untuk mempromosikan dirinya.

4. Supervision; Mengenai supervisi Luthans selanjutnya mengatakan bahwa "the abilities of the superiorto provide technical assistance and behavioral support", bahwa kemapuan atasan dibutuhkan untuk membantu secara teknis maupun dukungan perilaku.

5. Co-Workers; Yaitu dukungan dari rekan kerja dan lingkungan, seperti halnya dikutip oleh Luthans sebagai berikut: "the degree to which fellow workers are technically proficient and social supportive". Bagi kebanyakan karyawan, tempat kerja merupakan tempat untuk bersosialisasi, sehingga penting bagi mereka untuk memiliki rekan kerja yang dapat bekerjasama dan mendukung satu sama lain.

Berdasarkan teori yang terulas diatas di atas, maka pada penelitian ini kepuasan kerja dalam penelitian ini didefinisiskan sebagai : "Suatu perasaan yang menyokong atau tidak menyokong diri karyawan yang berhubungan dengan pekerjaannya maupun kondisi dirinya." Thomas (2010:117) kemudian Kepuasan Kerja diukur melalui indikator, keterlibatan dalam pengambilan keputusan, dampak penghargaan, dukungan pegawai dalam organisasi, ketepatan fungsi staf.

\subsection{Gaya Kepemimpinan}

Siagian (2012:62) mengemukakan bahwa kepemimpinan adalah kemampuan seseorang untuk mempengaruhi orang lain (para bawahannya) sedemikian rupa sehingga orang lain itu mau melakukan kehendak pemimpin meskipun secara pribadi hal itu mungkin tidak disenanginya. Siagian (2012:66) mengemukakan bahwa peranan pemimpin atau kepemimpinan dalam organisasi atau perusahaan ada tiga bentuk yaitu peranan yang bersifat interpersonal, peranan yang bersifat informasional, dan peran pengambilan keputusan.

Peranan yang bersifat interpersonal dalam organisasi adalah bahwa seorang pemimpin dalam perusahaan atau organisasi merupakan simbol akan keberadaan organisasi, seorang pemimpin bertanggung jawab untuk memotivasi dan memberikan arahan kepada bawahan, dan seorang pemimpin mempunyai peran sebagai penghubung. Peranan yang bersifat informasional mengandung arti bahwa seorang pemimpin dalam organisasi mempunyai peran 
sebagai pemberi, penerima dan penganalisa informasi.

Menurut Simonton dalam Haryono (2010:6) keberhasilan kepemimpinan bukan hanya dipengaruhi oleh sifat dasar (trait), namun dipengaruhi oleh beberapa fungsi faktor-faktor berikut, seperti : bakat, tempat dan waktu yang tepat. Simonton mengatakan:" Leadership excellent is a function of the right person, being in the right place and in the right time". Pemimpin yang efektif akan membantu mengembangkan kerja tim dalam pertemuanpertemuan sebagai sarana untuk meningkatkan kreativitas. (Rivai, 2011 : 95).

Sedangkan peran pemimpin dalam pengambilan keputusan mempunyai arti bahwa pemimpin mempunyai peran sebagai penentu kebijakan yang akan diambil berupa strategistrategi bisnis yang mampu untuk mengembangkan inovasi, mengambil peluang atau kesempatan dan bernegosiasi dan menjalankan usaha dengan konsisten.

Mintzberg, H (2000) mengemukakan bahwa peran kepemimpinan dalam organisasi adalah sebagai pengatur visi, motivator, penganalis, dan penguasaan pekerjaan. Pasolong (2010:6) mengemukakan bahwa keberhasilan kegiatan usaha pengembangan organisasi, sebagian besar ditentukan oleh kualitas kepemimpinan atau pengelolanya dan komitmen pimpinan puncak organisasi untuk investasi energi yang diperlukan maupun usaha-usaha pribadi pimpinan.

Davis et al. (2008 : 46) mengemukakan bahwa ada sembilan peranan kepemimpinan seorang dalam organisasi yaitu pemimpin sebagai perencana, pemimpin sebagai pembuat kebijakan, pemimpin sebagai ahli, pemimpin sebagai pelaksana, pemimpin sebagai pengendali, pemimpin sebagai pemberi hadiah atau hukuman, pemimpin sebagai teladan dan lambang atau simbol, pemimpin sebagai tempat menimpakan segala kesalahan, dan pemimpin sebagai pengganti peran anggota lain.

Gaya Kepemimpinan adalah urusan semua orang (leadership is every body's bisnis) karena setiap manusia adalah pemimpin, minimal memimpin dirinya sendiri serta bertanggung jawab atas kepemimpinannya. Teori kepemimpinan terdiri atas teori kepemimpinan klasik dan teori kepemimpinan modern. Secara skematik bagian atau subbagian dari masing-masing teori tersebut nampak sebagai berikut :

Tabel 2.

Teori Kepemimpinan Klasik dan Modern

\begin{tabular}{lll}
\hline \multicolumn{1}{c}{ Teori Kepemimpinan Klasik } & Teori Kepemimpinan Modern \\
\hline 1. Gaya Kepemimpinan model Taylor & 1. Teori Orang besar (great man) \\
2. Gaya Kepemimpinan model Mayo & 2. Sifat-sifat (Traits) \\
3. Studi Lova & 3. Perilaku (Behavioral) \\
4. Studi Ohio & 4. Situasional (Kontingensi) \\
5. Studi Michigan & 5. Transaksional \\
& 6. Transformasional \\
& 7. Pancasila \\
\hline
\end{tabular}

Sumber T. Hani Handoko (2011).

Pengertian gaya kepemimpinan secara umum dapat diartikan sebagai cara-cara atau perilaku yang diterapkan atau dipergunakan oleh seseorang pemimpin dalam mempengaruhi dan menggerakkan bawahannya agar melakukan kegiatan kerja menuju tercapainya tujuan yang telah ditentukan. Dalam pelaksanaan suatu kepemimpinan tidak terlepas dari perilaku atau cara yang diterapkan oleh pemimpin dalam mempengaruhi bawahannya, dengan kata lain bawahan akan menjalankan tugas / pekerjaan secara efektif dan produktif.

Mary Parker Follet yang mengembangkan hukum situasi seperti yang dikutip oleh Handoko, T. Hani (2011 : 53) mengatakan bahwa ada tiga variabel kritis yang mempengaruhi gaya pemimpin, yaitu 
kemampuan dan kualitas pemimpin, kemampuan dan kualitas pengikut bawahan, dan situasi.

Dari uraian di atas gaya kepemimpinan yang dimaksud dalam penelitian ini adalah menurut Siagian (2012:62) yaitu: "Gaya Kepemimpinan adalah kemampuan seseorang untuk mempengaruhi orang lain (para bawahannya) sedemikian rupa sehingga orang lain itu mau melakukan kehendak pemimpin meskipun secara pribadi hal itu mungkin tidak disenanginya."

Untuk mengukur gaya Kepemimpinan dalam penelitian ini dikembangkan dari teori kepemimpinan situasional Paul Hersey dan Ken Blanchard dalam Wirjana dan Robbins (2010:48) yang terdiri dari 4 (empat) indikator Gaya Kepemimpinan, yaitu :

1. Memberitahukan dan Menunjukkan

2. Kemampuan memberikan ide-ide kepada anggota

3. Kemampuan berpartisipasi dengan anggota

4. Kemampuan mendelegasikan kepada anggota

\subsection{Kinerja}

Keefektifan individu sering juga disebut dengan istilah kinerja pegawai atau Kinerja pegawai individu, dan jika dikaitkan dengan organisasi militer sering disebut dengan istilah Kinerja pegawai. Selanjutnya untuk membahas lebih lanjut mengenai Kinerja pegawai, perlu disamakan terlebih dulu pengertian mengenai Kinerja pegawai .

Greenberg yang dikutip oleh Siagian (2012:18) mendefinisikan Kinerja pegawai sebagai perbandingan antara totalitas pengeluaran pada waktu tertentu dibagi dengan totalitas masukan selama periode tersebut. Kinerja pegawai juga diartikan sebagai tingkatan efisiensi dalam memproduksi barang dan jasa, Kinerja pegawai mengutarakan cara pemanfaatan secara baik terhadap sumber-sumber dalam memproduksi barang dan jasa. Kinerja pegawai dalam organisasi adalah sejauh mana sumbangan dalam organisasi itu dapat mencapai tujuan atau sasaran organisasi.
Dengan demikian secara umum dapat dikemukakan bahwa Kinerja pegawai merupakan suatu ukuran bagi dalam mengabdikan dirinya pada organisasi untuk mencapai tujuan yang telah ditentukan sebelumnya. Dari sudut pandang teori psikologi, Kinerja pegawai merupakan proses tingkah laku kerja seseorang sehingga menghasilkan sesuatu yang menjadi tujuan dari pekerjaanya. Perbedaan antara satu individu dengan individu yang lain dapat berbeda dikarenakan sifat-sifat individu itu sendiri atau mungkin karena situasi yang berbeda. Dengan demikian Kinerja pegawai sebenarnya dapat memuaskan atau tidak tergantung pada faktor individu dan situasi atau lingkungan kerjanya. Faktor individu yang sangat penting dalam kaitannya dengan Kinerja pegawai adalah motivasi, sedangkan faktor situasi yang paling penting dalam mempengaruhi Kinerja pegawai adalah gaya kepemimpinan.

Kinerja pegawai pegawai administratif yang hasil pekerjaannya tidak dapat diukur secara kulitatif absolut, maka dapat digunakan pendekatan melalui tiga komponen, yaitu Greenberg yang dikutip oleh Siagian (2012:88): 1) Kualitas kerja; 2) Kuantitas kerja; 3) Tanggung jawab

Dalam Penelitian ini kinerja pegawai mengutip konsep yang dikemukakan oleh Greenberg yang dikutip oleh Siagian (2012) mendefinisikan Kinerja pegawai sebagai "Kemampuan pegawai dalam memberikan kemampuannya pada organisasi untuk dapat mencapai tujuan atau sasaran organisasi."

Dengan indikator pencapaian konsep adalah 1) Kualitas kerja. 2) Kuantitas kerja.; 3) Tanggung jawab.

\subsection{Hipotesis}

1. Diduga Kepuasan Kerja berpengaruh terhadap Kinerja Pegawai Badan Pengelolaan Keuangan dan Aset Kabupaten Lampung Utara.

2. Diduga Gaya Kepemimpinan berpengaruh terhadap Kinerja Pegawai Badan Pengelolaan Keuangan dan Aset Kabupaten Lampung Utara.

3. Diduga Kepuasan Kerja dan Gaya Kepemimpinan berpengaruh terhadap 
Kinerja Pegawai Badan Pengelolaan Keuangan dan Aset Kabupaten Lampung Utara.

\section{METODE PENELITIAN}

\subsection{Jenis Penelitian}

Metode di sini berbentuk penelitian survei, Sugiono (2010) mengatakan bahwa penelitian survei adalah penelitian yang diakukan pada populasi besar maupun kecil, tetapi data yang dipelajari adalah data dari sampel yang diambil dari populasi tersebut, sehingga ditemukan kejadian-kejadian relatif, distribusi, dan hubungan antar variabel.

\subsection{Populasi dan Sampel}

Populasi yang diambil dalam penelitian ini adalah seluruh pegawai Badan Pengelolaan Keuangan dan Aset Kabupaten Lampung Utara baik tetap dan honorer. Berhubung jumlah populasi relatif kecil setelah dikurangi oleh penulis sebagai peneliti, maka penulis tidak mengadakan atau melakukan penarikan sampel untuk diteliti, karena dapat di jangkau seluruhnya. Hal ini berarti seluruh pegawai Badan Pengelolaan Keuangan dan Aset Kabupaten Lampung Utara menjadi responden atau sumber data (sampel jenuh) dalam penelitian ini dengan cara penyebaran kuesioner dengan jumlah responden sebesar 75 responden setelah dikurangi oleh pimpinan.

\subsection{Teknik Pengumpulan Data}

Dimensi pengukuran Kinerja pada penelitian ini menggunakan pendapat menggunakan dimensi yang dikemukakan Danison (dalam Arikunto, 2012 : 135) dan disusun dalam bentuk skala Likert. Data yang diperlukan dalam penelitian ini meliputi Sugiono, (2010 : 230). Data Primer, yakni data yang diperoleh langsung melalui penelitian, baik melalui penggunaan kuesioner maupun wawancara. Sedangkan Data skunder, data yang diperoleh dari teknik dokumentasi dengan memanfaatkan sumber-sumber yang berkaitan dan dapat mendukung obyek yang akan diteliti.

Teknik pengumpulan data dalam penelitian ini adalah sebagai berikut :

1. Kuesioner Daftar pertanyaan disebarkan secara tertutup dimana setiap pertanyaan sudah disediakan altenatif jawaban, sehingga responden hanya tinggal memilih salah satu alternatif jawaban yang dianggap sesuai kenyataan.

2. Studi Kepustakaan dan Dokumentasi

Dilakukan dengan cara melihat dan mempelajari berbagai bahan bacaan, seperti buku-buku teoritis, makalah ilmiah, jurnal, dokumen dan laporan-laporan, temasuk barbagai peraturan yang berkaitan dengan variabel penelitian.

\subsection{Teknik Analisis Data}

1) Uji Instrumen

Dalam penelitian ini tinggi rendahnya validitas instrumen menunjukkan sejauh mana data yang terkumpul tidak menyimpang dari gambaran tentang validitas yang dimaksud dengan menggunakan korelasi product moment yang dikemukakan oleh Pearson dalam Arikunto, (2012: 220) Kesesuaian harga $r_{x y}$ diperoleh dari perhitungan dengan menggunakan rumus diatas dibandingkan dengan tabel harga regresi moment dengan korelasi harga $r_{x y}$ lebih besar atau sama dengan regresi tabel, maka butir instrumen tersebut valid dan jika $r_{x y}$ lebih kecil dari regresi tabel maka butir instrumen tersebut tidak valid.

Reliabilitas adalah sesuatu instrumen cukup dapat dipercaya untuk digunakan sebagai alat pengumpul data karena instrumen tersebut sudah baik ( Arikunto, 2012 : 217). Pada penelitian ini untuk mencari reliabilitas instrumen menggunakan rumus alpha $\boldsymbol{\alpha}$, karena instrumen dalam penelitian ini berbentuk angket atau daftar pertanyaan yang skornya merupakan rentangan antara 1-5.

\section{2) Analisis Pembuktian Hipotesis}

Untuk analisis data dari responden yang diperoleh melalui kuesioner, digunakan analisis statistik. Analisis stasistik menurut Arikunto (2012 : 215) adalah yang digunakan seluruh rangkaian kerja suatu penelitian, diantaranya merumuskan hipotesis, menyusun instrumen peneltian, menentukan sampel, menganalisis data dan menarik suatu kesimpulan dari suatu penelitian. Berdasarkan hipotesis yang diajukan dalam penelitian ini, 
untuk mengetahui bentuk hubungan pengaruh antara variabel bebas $(X)$ terhadap variabel terikat $(Y)$ digunakan analisis statistik.

Dalam hal ini $r$ YX merupakan koefisien korelasi pearson untuk uji validitas dan alpha pada reliabilitas. Struktur hubungan variabel tersebut dapat dinyatakan ke dalam persamaan regresi, yaitu :

\section{$Y=b_{0}+$ \\ $b_{1} x_{1}+b_{2} x_{2}$}

Koefisien determinasi merupakan bagian dari keragaman total dari variabel tak bebas yang dapat diperhitungkan oleh keragaman variabel bebas dihitung dengan koefisien determinasi dengan asumsi dasar faktor-faktor lain di luar variabel dianggap tetap atau konstan. Untuk mengetahui nilai koefisien determinasi, maka dapat dihitung dengan menggunakan rumus (Sugiyono, 2010 : 165)

$$
K D=r^{2} \times 100 \%
$$

Keterangan hasil korefisien :
$\mathrm{KD}=0 \%$, berarti pengaruh (variabel $\mathrm{X}$ ) terhadap (variabel $Y$ ).

$K D=100 \%$, berarti pengaruh (variabel $X)$ terhadap (variabel Y).

\section{3) Hasil Analisis Penelitian}

Berdasarkan hasil analisis instrumen diketahui bahwa kuesioner atau instrumen penelitian telah siap dan dapat digunakan dalam melakukan pengambilan data guna mengungkap fenomena atau keadaan sesungguhnya yang hasilnya akan di jelaskan selanjutnya.

Kemudian uji Normalitas dan Homogenitas terpenuhi maka data siap untuk dilakukan uji regresi berganda guna pembuktian hipotesis penelitian. Hasil uji regresi linear berganda yang dilakukan dengan menggunakan program PASW dengan acuan hasil perhitungan analisis statistik data dijelaskan dalam gambar sebagai berikut:

Gambar 3.

Rangkuman Hasil Analisis Penelitian

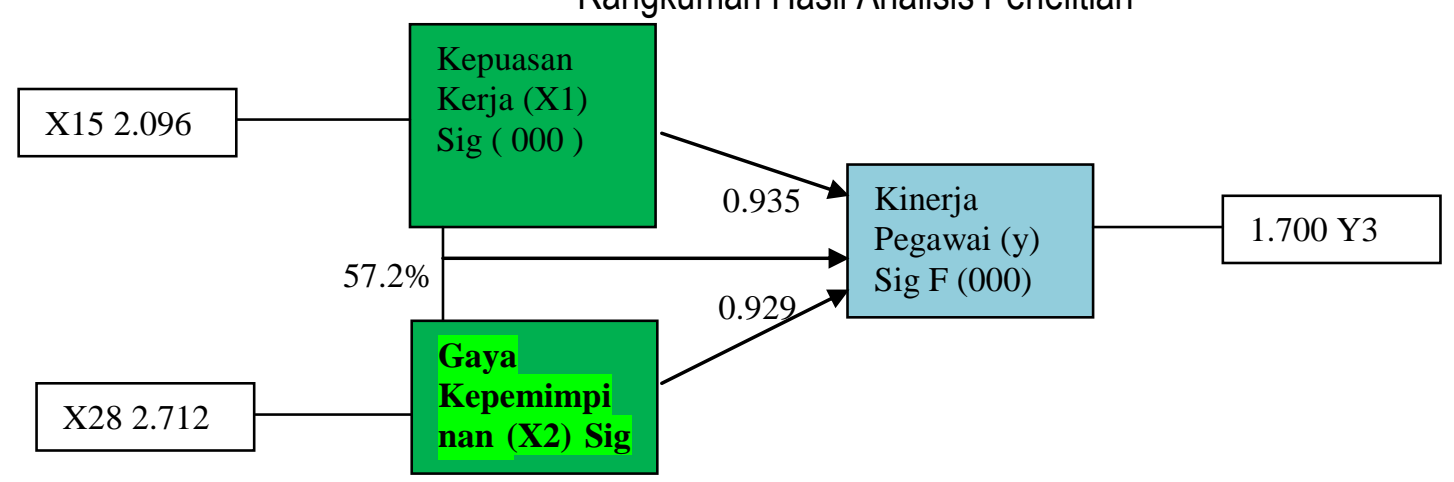

Sumber Rangkuman Hasil Analisis PASW

Pembahasan dari hasil rangkuman analisis tersebut maka gambar tersebut dapat diinterpretasikan bahwa Kepuasan Kerja dan Gaya Kepemimpinan memiliki pengaruh dengan kriteria sedang (57,2\%) terhadap Kinerja Pegawai Badan Pengelolaan Keuangan dan Aset Kabupaten Lampung Utara dengan variabel Kepuasan Kerja sebagai variabel dominan yang mempengaruhi Kinerja Pegawai Badan Pengelolaan Keuangan dan Aset Kabupaten Lampung Utara dengan kontribusi sebesar (0.935). Pada variabel Kepuasan Kerja juga didapatkan bahwa butir X15 yaitu Anda mendapat dukungan dari rekan sejawat saat bekerja memiliki kontribusi yang paling kecil. Pada Variabel Gaya Kepemimpinan butir yang paling kecil kontribusinya adalah X28 yaitu Anda mengetahui apa yang harus dilakukan untuk menggantikan pimpinan anda. Kemudian Pada variabel Kinerja Pegawai butir yang paling kecil dalam membentuk variabel Kinerja Pegawai adalah Y3 yaitu Anda selalu mengejar jumlah pekerjaan yang diselesaikan dengan baik. Dari pengolahan data juga didapatkan bahwa masih ada variabel lain yang belum dimasukkan tetapi memiliki pengaruh pada Kinerja Pegawai Pegawai Badan Pengelolaan 
Keuangan dan Aset Kabupaten Lampung Utara dengan pengaruh sebesar $42,8 \%$.

\section{SIMPULAN DAN SARAN}

\subsection{Simpulan}

1. Kepuasan Kerja dan Gaya Kepemimpinan secara parsial berpengaruh terhadap Kinerja Pegawai Badan Pengelolaan Keuangan dan Aset Kabupaten Lampung Utara.

2. Kepuasan Kerja dan Gaya Kepemimpinan secara simultan berpengaruh terhadap Kinerja Pegawai Badan Pengelolaan Keuangan dan Aset Kabupaten Lampung Utara dengan koefisien determinasi sebesar $57,2 \%$ (persen) dari variasi perubahan pengaruh Kepuasan Kerja dan Gaya Kepemimpinan dapat menjelaskan Kinerja Pegawai Badan Pengelolaan Keuangan dan Aset Kabupaten Lampung Utara.

\subsection{Saran}

a. Pada Variabel Kepuasan Kerja sebagai variabel dominan yang mempengaruhi Kinerja pegawai adalah dengan memperbaiki hubunga kerja pegawai agar mendapat dukungan dari rekan sejawat saat bekerja dengan cara melakukan pengakraban pegawai dan sistem kerjasama pegawai.

b. Pada Variabel Gaya kepemimpinan sebagai salah satu variabel juga yang membentuk Kinerja Pegawai adalah melakukan perbaikkan pada kemampuan pegawai agar dapat mengetahui apa yang harus dilakukan untuk menggantikan pimpinan jika tidak ada dengan sistem delegasi.

c. Kemudian Variabel Kinerja Pegawai sebagai variabel terikat dalam penelitian ini adalah memperbaiki pegawai dalam menyelesaikan jumlah pekerjaan yang diselesaikan dengan baik dengan cara pelatihan dan kesempatan studi lanjut.

\section{DAFTAR PUSTAKA}

Arikunto, Suharmini.2012, Manajemen Penelitian, Jakarta, Rineka Cipta.

Cohen, William, 2011, Setiap Pemimpin Harus Baca Buku ini, Jakarta, Tangga Pustaka.

Davis Keith, New Strom, Jhon W. 2012, alih bahasa Agus Dharma, Perilaku Dalam Organisasi, Jilid I, Erlangga, Jakarta.

Handoko, T. Hani. 2011. Manajemen Personalia dan Sumber Daya Manusia. Yoyakarta: BPFE Press.

Kreitner \& Kinichi, 2013, Organizational Behavior, USA :Allyn And Bacon, Needham Heights

Miftah Thoha, 2013. Prilaku Organisasi Konsep Dasar Dan Aplikasinya. Jakarta: Raja Grafindo Persada.

Masaong, Tilomi, 2011, Kepemimpinan Berbasis Multiple Intelligence, Bandung, Alfabeta.

Rivai, Veithzal dan Mulyadi, Dedy, 2010, Kepemimpinan dan Perilaku Organisasi, Jakarta, Rajawali Press.

Rivai, Veithzal dan Sagala, 2011, Manajemen Sumber Daya Manusia untuk Perusahaan Dari Teori ke Praktik, Jakarta, Rajawali Press.

Sekaran Uma. 2010, Research Methods For Business, New York :John Wiley \& Sons, Inc.

Siagian Sondang P., 2012. Kiat Meningkatkan Produktivitas Kerja, Cetakan Pertama, , Jakarta: PT. Rineka Cipta.

Sugiono, 2010 Metode Penelitian Pendidikan, Penerbit Alfabeta, Bandung. 2010.

Thomas R, Dye 2010 Understanding Public Policy, Prentice-Hall, Inc, Englewood Cliffs, New Jersey. 